\title{
THE EXCHANGE RATE VOLATILITY AND EXPORT PERFORMANCE: THE CASE OF INDONESIA'S EXPORTS TO JAPAN AND US
}

\author{
Shinta Fitriani ${ }^{1}$
}

\begin{abstract}
This paper investigates the long-run and short-run impacts of the exchange rate volatility on Indonesia's real exports to its major trading partners; Japan and US. The study uses monthly data from January 1998 to October 2015 in order to capture the structural break period of the Global Financial Crisis 2008. In addition, commodity price is included as an explanatory variable. The index of exchange rate volatility is generated using moving sample standard deviation of the growth of the real exchange rate. This paper estimates the long-run cointegration using Autoregressive Distributed Lag (ARDL) bounds testing, while for the short-run dynamic this paper use error-correction-model (ECM). The findings suggest rupiah volatility against the Japanese yen reduces Indonesia's export to Japan, both in the short and the long-run. Fluctuation of rupiah against the US dollar helps Indonesia's export to the US in the short run, but the impact is not carried out to the long-run. On the other hand, the impact of commodity price shock is negligible, except for the long-run export to Japan.
\end{abstract}

Keywords: ARDL bounds testing, export, exchange rate volatility, Indonesia JEL Classification: C33, F14, F31

1 Shinta Fitriani (shinta_f@bi.go.id), Economic Analyst of International Department, Bank Indonesia. 


\section{INTRODUCTION}

Global economic downturn triggered by Global Financial Crisis 2008 had negatively affected the world trade. In terms of volume, global transaction contracted by more than 12 percent in 2009, compared with 7.52 percent of growth in 2008. Trade began to recover in 2010, largely due to the rise in commodity prices (WTO, 2010). However, unlike to other countries, the recovery did not prolong for Indonesia. Figure 1 shows that within ASEAN5 neighbouring countries, Malaysia, Thailand, and above all, Vietnam enjoyed positive growth of their exports, whereas Indonesia's export remained sluggish after 2011. Within this context, it is imperative to investigate why Indonesia could not sustain its export growth.

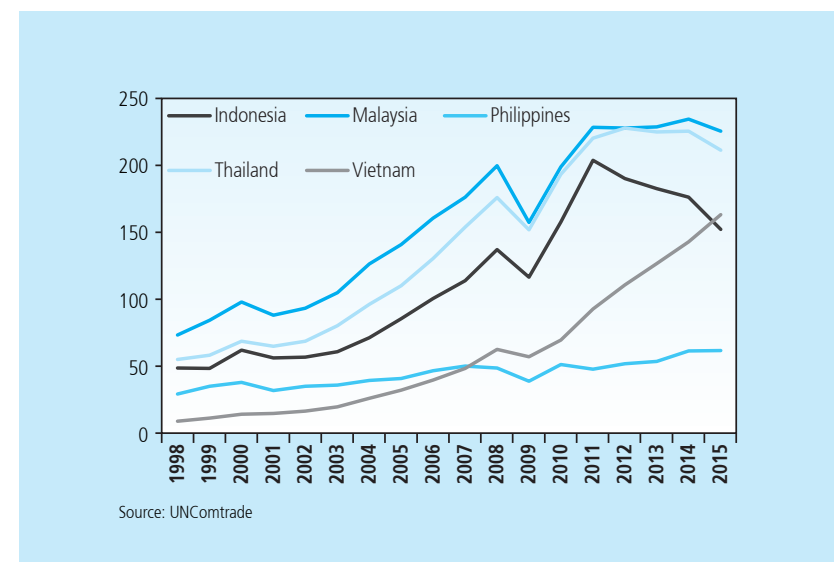

Figure 1. Total export of ASEAN5, 2000-2014 (billion US\$)

Drawing on international trade theories, one of the key economic factors which affect the trade performance is exchange rate movement. A change in the exchange rate, other things remain equal, will change all foreign prices relative to all domestic prices (Yarborough and Yarborough, 2006, p. 372) and therefore affect the export as well as import demands (Krugman, 2012, p.321). Exchange rate fluctuation also implies uncertainty and increases riskiness in the international transactions (Auboin and Ruta, 2012). Indonesia implements floating exchange rate arrangement since 14 August 1997. Being a small open economy, allowing its currency to move freely implies that rupiah is susceptible to factors such as capital flows fluctuation, market sentiment, as well as to developments in the offshore market (Warjiyo, 2013; Edwards and Sahminan, 2008). The pressure on rupiah has been intensified in the recent years (Figure 2), triggered by both domestic and external reasons. Therefore, it is rational to argue that Rupiah fluctuation, particularly against the USD and Yen, may have influenced Indonesia's export activities. 


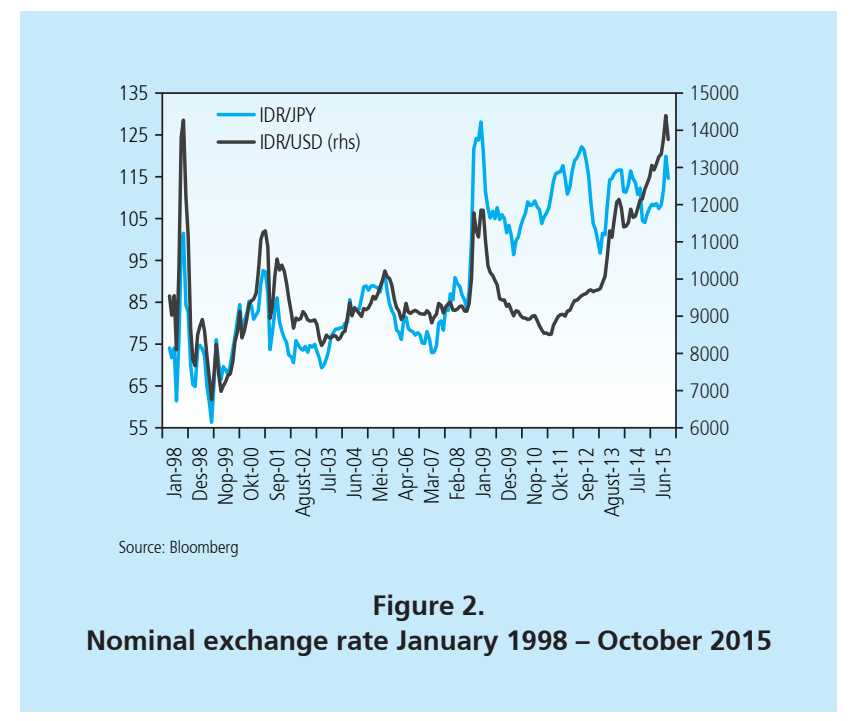

This paper aims to explore the long-run and short-run effects of rupiah volatility on Indonesia's exports, by focusing on bilateral export to Japan and the US. The two advanced economies are selected for this study because they are Indonesia's largest export markets which contributed to approximately 28.2 percent of Indonesia's total shipment during 1998-2014.

This study will focus on the exports during January 1998 - October 2015. The sample period is purposefully selected to cover only the period when Indonesia implements floating exchange rate regime and to exclude the Asian Financial Crisis 1997 episode. Furthermore, the period under observation captures the structural break of Global Financial Crisis 2008 in which economic activities in the US and Japan plummeted.

The study will contribute to existing literature through several ways. First, it can identify whether the impact of exchange rate volatility on export is similar across markets. Second, empirical study on the impact of rupiah volatility on Indonesia's export to Japan is still limited, albeit Japan is the largest market for Indonesian exports and despite the export performance has been falling (Figure 3). Third, this study will employ ARDL bounds testing introduced by Pesaran et al. (2001). The approach is still rarely used in the Indonesian case. Fourth, the study incorporates commodity price as a new explanatory variable in the model. The variable is important for Indonesia because the share of commodity in its export is relatively high (Figure 4) hence the export is susceptible to price movement in the global commodity market. 


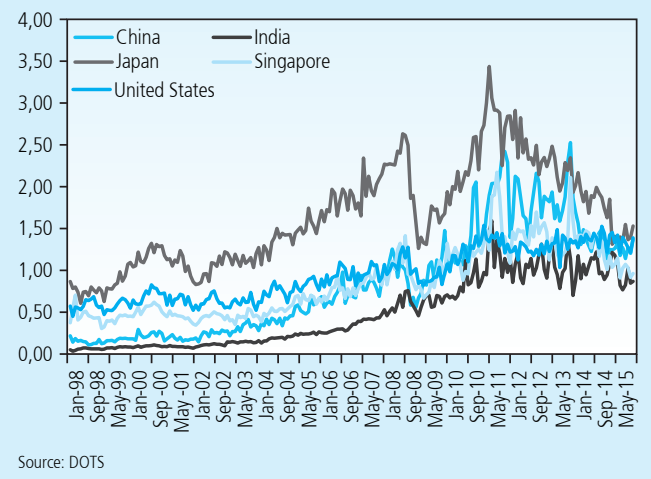

Figure 3. Indonesia's export to major trading partners, 1998-2015 (billion USD)

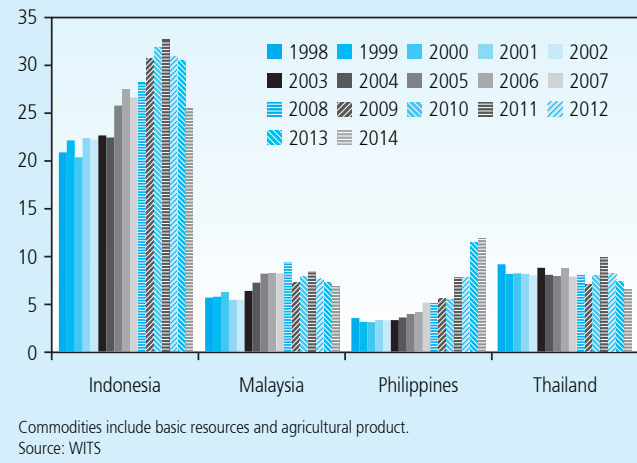

Figure 4. Share of Selected Commodities in Total Exports, 1998-2014 (percent)

The remainder of this paper is organized as follows. Section 2 outlines the literature review. Section 3 provides the data and estimated model, while Section 4 presents the empirical results along with the robustness tests, including the discussion. Conclusion and possible policy implications for Indonesia are provided in Section 5.

\section{THEORY}

Exchange rate movement plays a significant role in international trade. Empirical studies on the impact of exchange rate fluctuation on a country's trade have come up with varied conclusions and tend to be case-specific (Tsen, 2014). That is, the impact can be positive, negative, or neutral. The more common finding is exchange rate uncertainty impairs trade because it is considered to increase the risk in international transactions (Auboin and Ruta, 2012).

Majority of the studies suggest that the Rupiah's volatility against other currency negatively affect Indonesia's export. For instance, using panel data of Indonesia, Malaysia, Philippines, Thailand, and China, Chit et al. (2010) and Chit (2008) find currency swings impair bilateral trade between the countries under study as well as trade with other countries during 1982 to 2006. Baak (2004) obtains a similar finding on his panel study on 14 Asia Pacific countries, including Indonesia, with a sample period of 1980 to 2002. Doğanlar (2002) and Arize et al. (2000) obtain a negative relationship between exchange rate volatility and total world export during 1980 to 1996 and during 1973 until 1996, respectively. Likewise, research by Poon et al. (2005) on five East Asian countries using 1973 to 2002 data attain similar conclusion. Using monthly data from 1979 to 2003, Fang et al. (2006) concludes that depreciation supports Asian 
countries' exports to the US, while exchange rate volatility tends to discourage exports of the majority of the countries. For the case of Indonesia, the net effect is found to be negative.

Studies that specifically focus on the impact of rupiah movement on Indonesia's export were undertaken among others by Zainal (2004), Siregar and Rajan (2004), and Bustaman and Jayanthakumaran (2007). Using monthly data from July 1997 to August 2002, Zainal (2004) concludes that exchange rate volatility did not affect Indonesia's world export. Siregar and Rajan (2004) find a negative and significant impact of exchange rate fluctuation on Indonesia's import as well as export. Furthermore, they also suggest that the same impact occurred in Indonesia's export to Japan based on 1980Q2 to 1997Q2 data, or the period when Indonesia still adopted managed-floating exchange rate regime.

At the commodity level, Bustaman and Jayanthakumaran (2007) obtain a mixed result on the long-run and short-run influence of rupiah volatility on the export volume of 18 commodities to the U.S. However, the effect is negative for most of the commodities in the long-run. Bahmani-Oskooee et al. (2015) investigates on the trade of 32 industries between the USA and Indonesia. Their finding show $66 \%$ of the industries under study are affected by movement of real exchange-rate in the short run. The effects continue to the long-run on a third of them.

This paper provides empirical analysis between the exchange rate volatility and the export growth for Indonesian case using more recent data. By including the crisis period of Global Financial Crisis (GFC) 2008, and the period of unconventional policies undertaken by various advanced economies in the aftermath of the crisis, we may expect the analysis will capture the exchange rate shock and its impact on the export. In addition, commodity price is still omitted in the existing model, although commodity plays a substantial role in Indonesia's export.

The export demand model may be specified as in Doğanlar (2002). That is, a standard export demand model augmented by an exchange rate volatility variable. To internalize the commodity prices and the crisis episode, one can modify this standard model as follows:

$$
\ln X_{i t}=\alpha_{1 i}+\alpha_{2 i} \ln Y_{i t}+\alpha_{3 i} \ln R P_{i t}+\alpha_{4 i} V_{i t}+\alpha_{5 i} D_{i t}+\alpha_{6 i} \ln C_{t}+e_{i t}
$$

where: $X_{i t}$ is the export volume to country $i$ at time $t ; Y_{i t}$ is country $i$ 's income at time $t ; R_{i t}$ is the relative price between host and country $i$ at time $t ; V_{i t}$ is the volatility of bilateral exchange rate against country $i ; D_{\text {it }}$ is a dummy variable corresponds to the GFC 2008 for country $i$ at time $t$, and $C_{t}$ is the world's commodity price index at time $t$.

According to international trade theory, an increase in trading partner's income will stimulate export, thus the sign of $\alpha_{2 i}$ is expected to be positive. On the other hand, any increase in relative prices is predicted to discourage export, hence the sign of $\alpha_{3 i}$ is expected to be negative. The variable signs for the exchange rate volatility and the commodity price indexes are still undetermined and subject to the outcomes of this study. 
On estimating the above model, some limitation on the data availability may occur. For this reason, the volume of export may be estimated from the export value $\left(X V \mathrm{Va}_{i t}\right)$ divided by the export price index $\left(X P_{t}\right)$. This approach was used Siregar and Rajan (2004).

$$
X_{i t}=\frac{X V a l_{i t}}{X P_{t}}
$$

The choice of income proxy is usually the GNP or the Industrial Production Index. For relative price, one can use the ratio of domestic export price index $\left(X P_{t}\right)$ to the trading partner's export price index $\left(X P_{i t}\right)$, (Doğanlar, 2002):

$$
\mathrm{RP}_{\mathrm{it}}=\frac{X P_{t}}{X P_{i t}}
$$

The exchange rate to calculate the volatility at time $t$ is based on the real exchange rate:

$$
R E R_{i t}=\frac{E_{i t} \times C P I_{i t}}{C P I_{t}}
$$

where $E_{i t}$ denotes the monthly average of nominal exchange rate of rupiah against country i's currency; $C P_{i t}$ and $C P I_{t}$ denote consumer price index of trading partner $i$ and Indonesia's consumer price index respectively. The real exchange rate is used because it is considered to be and appropriate indicator to measure volatility in the macroeconomic analysis (Bahmani-Oskooee dan Durmaz, 2016). The currency volatility will be measured using the moving sample standard deviation of the growth of the bilateral real exchange rate (RER), following Doğanlar (2002):

$$
V_{i_{t}}=\left[\frac{1}{h_{i}} \sum_{j=1}^{h_{i}}\left(\ln (R E R)_{i_{t}}-\ln (R E R)_{i_{t-1}}\right)^{2}\right]^{1 / 2}
$$

$h$ is the order of the moving average which will be determined using both Akaike Information Criterion (AIC) and Schwarz Criterion (SC).

\section{METHODOLOGY}

\subsection{ARDL Bounds Test}

This paper will use ARDL bounds testing of Pesaran et al. (2001) to estimate the long-run cointegration between the variables. The approach has several advantages compared to other econometric models. First, it gives valid results of cointegration test whether the underlying series are I(1) or I(0), or a combination of both. Second, the test is reliable for the case that 
involves structural breaks. Third, it can be used for small-sample size which typically occurs in the developing countries data.

In order to use the ARDL bounds test cointegration approach, we need to ensure that the stationarity of all variables is not I(2). The stationarity is checked using Augmented-Dickey-Fuller unit root test. In addition, Breakpoint Unit Root Test with Innovational Outlier is undertaken to identify the existence of structural break in the data and the period when the structural change began.

To proceed the use of ARDL bounds testing method, Eq. (1) is transformed into a conditional ARDL-ECM as follows:

$$
\begin{aligned}
\Delta \ln X_{i t}=c+\sum_{j=1}^{k} & \alpha_{i j} \Delta \ln X_{i_{t-j}}+\sum_{j=0}^{l} \beta_{i j} \Delta \ln Y_{i_{t-j}}+\sum_{j=0}^{m} \gamma_{i j} \Delta \ln R P_{i_{t-j}}+\sum_{j=0}^{n} \delta_{i j} \Delta V_{i_{t-j}} \\
& +\sum_{j=0}^{p} \theta_{i j} \Delta \ln C_{t-j}+\lambda_{1 i} \ln X_{i_{t-1}}+\lambda_{2 i} \ln Y_{i_{t-1}}+\lambda_{3 i} \ln R P_{i_{t-1}} \\
& +\lambda_{4 i} V_{i_{t-1}}+\lambda_{5 i} D_{i_{t-1}}+\lambda_{6 i} \ln C_{t-1}+u_{i t}
\end{aligned}
$$

where $k, I, m, n$, and $p$ are optimal lags of the model.

Eq. (6) encompasses estimates for the short-run as well as long-run relationships in a single equation. The short-run effects are indicated by the coefficients of the first-differenced variables $\left(\alpha_{i j} \beta_{i j} \gamma_{i j^{\prime}} \delta_{i j^{\prime}}\right.$ and $\left.\theta_{i j}\right)$ while the long-run effects are reflected in $\lambda_{2 i}$ to $\lambda_{6 i}$. The parameters are estimated using Ordinary Least Square (OLS) method iteratively until the optimal lags of the variables (i.e. the values of $k, I, m, n$, and $p$ ) are obtained. The process of lag selection follows a general-to-specific approach. That is, by starting with a maximum lag and then removing the regressors that are found to be insignificant. The final model is the one that gives the lowest values of Akaike Information Criteria (AIC), Schwartz-Bayesian Criteria (SBC), and HannanQuinn Criterion (HQC).

The presence of long-run relationship between the variables is confirmed using F-test for joint significance of the lagged level variables of Eq. (6). The null hypothesis is no long-run relationship between variables, or $H_{0}: \lambda_{1}=\lambda_{2}=\lambda_{3}=\lambda_{4}=\lambda_{5}=\lambda_{6}=0$ against the alternative hypothesis $H_{1}: \lambda_{1} \neq \lambda_{2} \neq \lambda_{3} \neq \lambda_{4} \neq \lambda_{5} \neq \lambda_{6} \neq 0$. The resulted F-stat value is compared against the two sets of adjusted critical value bounds that established lower and upper bounds of significance as tabulated by Pesaran et al. (2001). If the F-stat is less than the lower bound, then the null hypothesis is not rejected. If the F-stat value exceeds the upper bound, then the null hypothesis is rejected. Otherwise, the cointegration between variables cannot be concluded. Afterwards, diagnostic test on the residuals and stability test are conducted to examine the robustness of the models. 


\subsection{Data}

The analysis is conducted on a monthly basis. The sample period that will be used in this study is from January 1998 to October 2015. Table 1 shows the overall data sets and their sources. The descriptive statistics of the variables in natural logarithm are shown in Table 2.

\begin{tabular}{|c|c|c|}
\hline \multicolumn{3}{|c|}{$\begin{array}{c}\text { Table } 1 . \\
\text { Data Sources }\end{array}$} \\
\hline No. & Variable & Source \\
\hline 1. & Indonesia Export Values to the US and to Japan & DOTS \\
\hline 2. & Indonesia Export Price Index & Tradingeconomics \\
\hline 3. & Industrial Production (IP) Indexes and Japan IP Index & CEIC \\
\hline 4. & US Export Price Index & FRED \\
\hline 5. & Japan Export Price Index & Bank of Japan \\
\hline 6. & Daily Nominal Exchange Rate of IDR/USD and IDR/JPY & Bloomberg \\
\hline 7. & Indonesia Consumer Price Index (CPI) & Tradingeconomics \\
\hline 8. & Consumer Price Indexes (CPI) of the US and Japan & CEIC \\
\hline 9. & Commodity Price Index & IMF \\
\hline
\end{tabular}

\begin{tabular}{|c|c|c|c|c|c|}
\hline \multicolumn{6}{|c|}{$\begin{array}{c}\text { Table } 2 . \\
\text { Descriptive Statistics of The Variables (In Natural Log) }\end{array}$} \\
\hline & Mean & Median & Maximum & Minimum & Standard Deviation \\
\hline \multicolumn{6}{|l|}{ Trading Partner: Japan } \\
\hline Export Volume & 16.742 & 16.779 & 17.173 & 16.126 & 0.201 \\
\hline IP Index & 4.616 & 4.62 & 4.831 & 4.297 & 0.090 \\
\hline Relative Price & -0.317 & -0.296 & 0.307 & -1.292 & 0.476 \\
\hline Real Exchange Rate & 9.472 & 9.411 & 10.403 & 9.128 & 0.243 \\
\hline \multicolumn{6}{|c|}{ Trading Partner: United States } \\
\hline Export Volume & 16.204 & 16.177 & 16.64 & 15.855 & 0.158 \\
\hline IP Index & 4.578 & 4.569 & 4.681 & 4.468 & 0.056 \\
\hline Relative Price & -0.316 & -0.217 & 0.093 & -1.012 & 0.299 \\
\hline Real Exchange Rate & 4.901 & 4.801 & 5.812 & 4.505 & 0.273 \\
\hline Commodity Price Index & 4.632 & 4.729 & 5.393 & 3.737 & 0.492 \\
\hline
\end{tabular}

\subsection{Robustness Analysis}

Diagnostic and the stability tests are conducted in order to ascertain the robustness of the ARDL model. The results (Table 3 ) show that in both cases, the $R^{2}$ and adjusted $R^{2}$ are sufficiently high. Accordingly, the models fit the data very well. Almost all of the $\mathrm{p}$-values of the diagnostic tests exceed 0.05 , indicating the models are correctly specified. The $p$-values of the serial correlation 
tests using Breusch-Godfrey LM test with lag $=4$ are 0.253 and 0.477 , which imply that there are no autocorrelation problems. The results of the heteroscedasticity tests of ARCH LM and Breusch-Pagan-Godfrey also show that there are no heteroscedasticity issues in the models. Likewise, stability tests using the Ramsey's RESET (Regression Equation Specification Error Test) tests indicate that there is no specification error in the models.

\begin{tabular}{|c|c|c|}
\hline \multicolumn{3}{|c|}{$\begin{array}{c}\text { Table } 3 . \\
\text { Goodness of Fit, Diagnostic Tests and Stability Tests }\end{array}$} \\
\hline & Trading partner: Japan & Trading partner: United States \\
\hline \multicolumn{3}{|l|}{ Goodness of fit } \\
\hline $\mathrm{R} 2$ & 0.787 & 0.749 \\
\hline Adjusted R2 & 0.778 & 0.734 \\
\hline \multicolumn{3}{|l|}{ Diagnostic tests } \\
\hline Serial Correlation $\chi_{S C}^{2}(4)$ & $5.354[0.253]$ & $3.376[0.497]$ \\
\hline Heteroscedasticity $\chi_{B P-L M}^{2}$ & $10.789[0.214]$ & $17.671[0.126]$ \\
\hline Heteroscedasticity $\chi_{A R C H-L M}^{2}(1)$ & $0.093[0.760]$ & $0.335[0.563]$ \\
\hline \multicolumn{3}{|l|}{ Stability test } \\
\hline Ramsey RESET test (1) & $0.001[0.973]$ & $0.159[0.690]$ \\
\hline
\end{tabular}

The stabilities of the models are evaluated through their CUSUM and CUSUM-SQ statisticS (Figure 5 to 8). For the case of export to the US (Figure 7 and 8), both CUSUM and CUSUM-SQ statistics are within the $95 \%$ confidence bands, hence we conclude the model is stable. For the case of export to Japan, the CUSUM plot (Figure 6) affirms the model's stability. Nevertheless, some points in the CUSUM-SQ graph from January 2013 to September 2015 are marginally crossing the critical value lines. Despite that, as all of other robustness tests are supportive to the current model, we can establish that the model is stable.

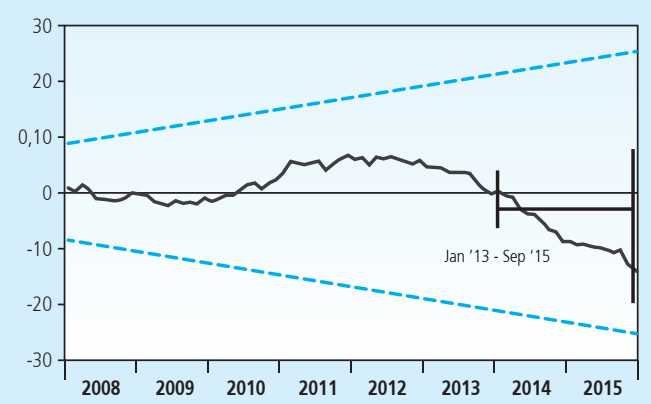

Figure 5. CUSUM of export to Japan

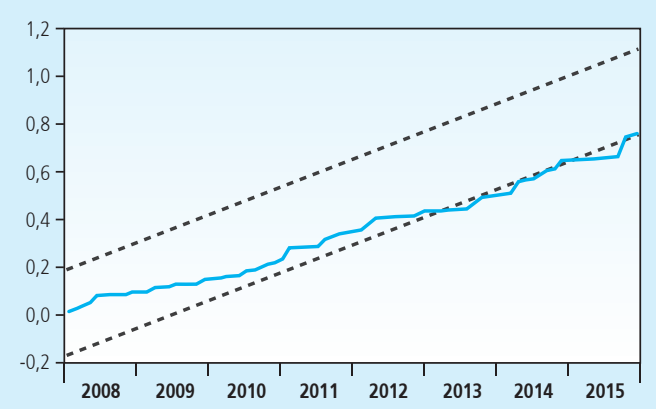

Figure 6. CUSUMSQ of export to Japan 


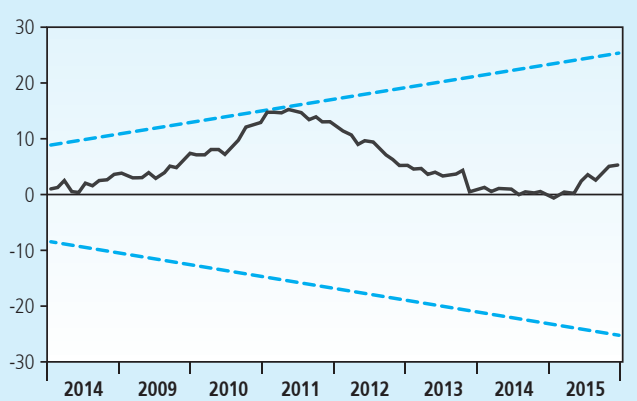

Figure 7. CUSUM of export to the US

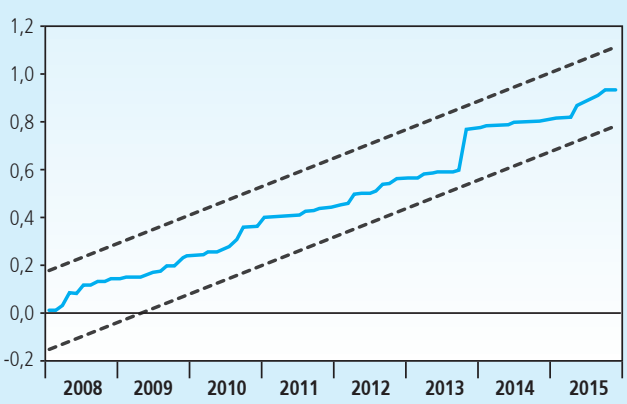

Figure 8. CUSUMSQ of export to the US

\section{RESULT AND ANALYSIS}

\subsection{Exchange Rate Volatility Measurement}

The first step of the study is to generate the index of exchange rate volatility using Eq. 5. The resulted order of moving average $(h)$ of the bilateral real exchange rate between rupiah against the Japanese yen and US dollar are 2 and 4, respectively, because they have the lowest AIC, $\mathrm{SIC}$ and HQC values. The lags are incorporated into Eq. (5) to obtain the volatility index. The resulted index is plotted in Figure 9 . The graph shows that rupiah was extremely volatile during the first period of observation, and some spikes recurred in several periods. In addition, rupiah tends to be more unstable against yen than against the US dollar.

\begin{tabular}{|c|c|c|c|c|c|c|c|c|}
\hline \multicolumn{9}{|c|}{$\begin{array}{c}\text { Table } 4 . \\
\text { Lag Selection of The Moving Average of The Bilateral RER }\end{array}$} \\
\hline \multirow{2}{*}{ Criteria } & \multicolumn{3}{|c|}{ Trading partner: Japan } & \multicolumn{5}{|c|}{ Trading partner: USA } \\
\hline & $\operatorname{Lag} 1$ & $\operatorname{Lag} 2$ & Lag 3 & $\operatorname{Lag} 1$ & Lag 2 & Lag 3 & Lag 4 & Lag 5 \\
\hline AIC & -6.876 & -7.038 & -6.870 & -6.735 & -6.927 & -6.716 & -7.046 & -6.734 \\
\hline SC & -6.829 & -6.991 & -6.822 & -6.687 & -6.880 & -6.669 & -6.998 & -6.687 \\
\hline HQC & -6.857 & -7.019 & -6.851 & -6.715 & -6.908 & -6.697 & -7.027 & -6.715 \\
\hline
\end{tabular}




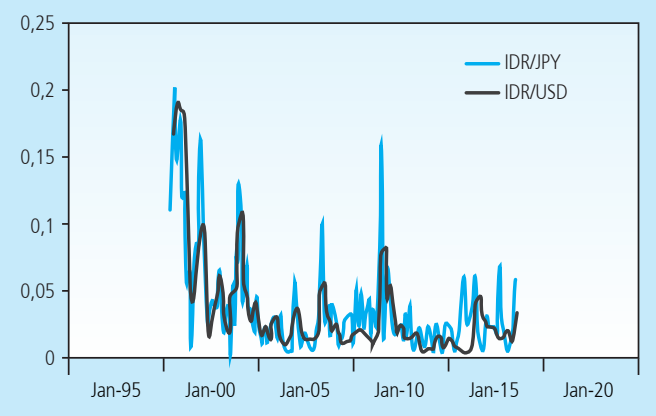

Source: calculated.

Figure 9. Estimates of RER volatility index

\subsection{Test of Order of Integration and Structural Break}

The level of stationarity of each variable is examined using the Augmented Dickey-Fuller (ADF) unit root test, with Schwarz Info Criterion and 12 maximum lag. All variables are in natural log, except the real exchange rate (RER) volatility index. The test results (Table 5) indicate that there is a mixture of orders of integration, and no variable is I(2). Therefore, ARDL bounds test can be applied in evaluating the cointegration between the variables.

\begin{tabular}{|c|c|c|c|c|c|c|}
\hline \multicolumn{7}{|c|}{$\begin{array}{l}\text { Table } 5 . \\
\text { Augmented Dickey-Fuller (ADF) Unit Root Test }\end{array}$} \\
\hline \multirow{2}{*}{ Variable } & \multicolumn{2}{|c|}{ Level } & \multicolumn{2}{|c|}{ 1st Difference } & \multirow{2}{*}{$\begin{array}{l}\text { Order of } \\
\text { Integration }\end{array}$} & \multirow{2}{*}{ Break Date } \\
\hline & t-stat & p-value & t-stat & p-value & & \\
\hline \multicolumn{7}{|l|}{ Trading partner: Japan } \\
\hline Export Volume & -3.230 & 0.020 & \multirow{4}{*}{-11.841} & \multirow{4}{*}{0.000} & $\mathrm{I}(0)$ & \\
\hline Relative Price & -1.583 & 0.490 & & & $\mathrm{I}(1)$ & \\
\hline RER Volatility Index & -5.481 & 0.000 & & & $\mathrm{I}(0)$ & \\
\hline Japan IP Index & -7.492 & $<0.01$ & & & $\mathrm{I}(0)$ & 2008M09 \\
\hline \multicolumn{7}{|c|}{ Trading partner: United States } \\
\hline Export Volume & -3.301 & 0.016 & \multirow{4}{*}{-11.301} & \multirow{4}{*}{0.000} & $\mathrm{I}(0)$ & \\
\hline Relative Price & -1.566 & 0.498 & & & $\mathrm{I}(1)$ & \\
\hline RER Volatility Index & -5.922 & 0.000 & & & $\mathrm{I}(0)$ & \\
\hline US IP Index & -8.131 & $<0.01$ & & & $\mathrm{I}(0)$ & 2008M07 \\
\hline Commodity Price Index & -3.352 & 0.776 & -10.796 & $<0.01$ & $\mathrm{I}(1)$ & 2008M10 \\
\hline
\end{tabular}


Breakpoint unit root test with Innovation Outlier break type is exercised for the industrial production (IP) index and commodity price index. The resulted Break Dates for the Japan IP, US IP, and commodity price indexes are September 2008, July 2008, and October 2008, respectively (Table 4). The break dates become the reference for values of the dummy variables, $D_{i t}$. For example, for the case of export to Japan, $D_{i t}$ is 1 from September 2008 until the end of the period under study, and 0 otherwise. The break date of commodity price index is already covered by $D_{i t}$ because the Break Date is later than that of the IP Index.

\subsection{ARDL Bounds Testing for Long-Run Cointegration}

The first step of the ARDL bounds test is to find the optimal lag length of the regressors according to Eq. (6). The lag selection process will follow a general-to-specific approach by starting with a maximum lag of $4(\max k=\max I=\max m=\max n=\max p=4)$. This initial lag is chosen in order to have as minimum lags as possible and result in a more parsimonious model (Verbeek, 2008, p. 299). The optimal lag structures given by the models with the lowest AIC, SC, and $\operatorname{HQC}$ values are $\operatorname{ARDL}(2,0,1,0,0)$ and $\operatorname{ARDL}(2,3,1,1,0)$ for each case respectively (Table 6).

\begin{tabular}{|c|c|c|c|c|}
\hline \multicolumn{5}{|c|}{$\begin{array}{c}\text { Table } 6 . \\
\text { Finding The Optimal Structure of The ARDL Specification }\end{array}$} \\
\hline Criteria & Selected ARDL Model & AIC & SC & HQC \\
\hline \multicolumn{5}{|c|}{ Trading partner: Japan } \\
\hline AIC & $\operatorname{ARDL}(3,0,2,0,4)$ & -1.834 & -1.595 & -1.737 \\
\hline SC & $\operatorname{ARDL}(2,0,1,0,0)$ & -1.826 & -1.683 & -1.768 \\
\hline $\mathrm{HQ}$ & $\operatorname{ARDL}(3,0,2,0,0)$ & -1.827 & -1.653 & -1.757 \\
\hline \multicolumn{5}{|c|}{ Trading partner: United States } \\
\hline AIC & $\operatorname{ARDL}(3,3,2,3,0)$ & -2.143 & -1.869 & -2.032 \\
\hline SC & $\operatorname{ARDL}(2,3,1,1,0)$ & -2.135 & -1.927 & -2.051 \\
\hline $\mathrm{HQ}$ & $\operatorname{ARDL}(2,3,1,1,0)$ & -2.135 & -1.927 & -2.051 \\
\hline
\end{tabular}

The next step is to check whether long-run relationship between the variables exists. This is undertaken by testing the null hypothesis of 'no long-run relationship' using an F-test for the joint significance of the lagged levels of the variables $\left(\lambda_{1}\right.$ to $\left.\lambda_{6}\right)$. The resulted F-statistics is compared to the critical values specified by Pesaran et al. (2001). The bounds for the case of unrestricted intercept and no trend with $k=4$ are 2.45 to 3.52 for $\alpha=10 \%, 2.86$ to 4.01 for $\alpha=5 \%, 3.25$ to 4.49 for $\alpha=2.5 \%$, and 3.74 to 5.06 for $\alpha=1 \%$ (Pesaran et al. 2001, p. 300). The resulted F-stat for the Japan case is 5.004, or higher than the critical value of $\alpha=$ $2.5 \%$, while that of the US case is 10.455 , or exceeds the critical value of $\alpha=1 \%$. Thus, the null hypothesis are rejected. In other words, a long-run relationship among the variables exists. 


\subsection{Estimated Model}

The subsequent step is to estimate the long-run and short-run relationships between the variables based according to the selected ARDL models. The results are shown in the following tables.

\begin{tabular}{|c|c|c|}
\hline \multicolumn{3}{|c|}{$\begin{array}{c}\text { Table } 7 . \\
\text { Estimates of Long-Run Coefficients }\end{array}$} \\
\hline Variable & Trading Partner: Japan & Trading Partner: United States \\
\hline Income & $0.752^{*}(0.418)$ & $1.504^{* * *}(0.327)$ \\
\hline Relative Price & $-1.389^{* * *}(0.279)$ & $-0.820^{* * *}(0.109)$ \\
\hline RER Volatility Index & $-2.237^{* * *}(0.842)$ & $0.378(0.385)$ \\
\hline Commodity Price Index & $0.943^{* * *}(0.206)$ & $0.034(0.059)$ \\
\hline GFC Dummy & $0.272^{\star *}(0.136)$ & $0.201^{* * *}(0.041)$ \\
\hline
\end{tabular}

\begin{tabular}{|c|c|c|}
\hline \multicolumn{3}{|c|}{$\begin{array}{c}\text { Table } 8 . \\
\text { Estimates of Short-Run Coefficients }\end{array}$} \\
\hline Variable & Trading Partner: Japan & Trading Partner: United States \\
\hline $\mathrm{D}($ Export Volume $(-1))$ & $-0.232^{\star * *}(0.062)$ & $-0.231^{* * *}(0.061)$ \\
\hline $\mathrm{D}$ (Income) & $0.181^{* *}(0.080)$ & $1.090^{\star * *}(0.337)$ \\
\hline $\mathrm{D}($ Income $(-1))$ & & $1.506^{\star \star \star}(0.383)$ \\
\hline $\mathrm{D}$ (Income $(-2)$ ) & & $1.453^{\star * \star}(0.336)$ \\
\hline $\mathrm{D}$ (Relative Price) & $-1.057^{\star \star *}(0.150)$ & $-1.052^{* * *}(0.142)$ \\
\hline D(RER Volatility Index) & $-0.607^{* *}(0.291)$ & $1.888^{* * *}(0.491)$ \\
\hline $\mathrm{D}$ (Commodity Price Index) & $0.205(0.136)$ & $0.048(0.117)$ \\
\hline Intercept & $2.145^{\star \star *}(0.386)$ & $4.771^{* * *}(0.656)$ \\
\hline D(GFC Dummy) & $0.062(0.097)$ & $0.057(0.081)$ \\
\hline $\mathrm{ECT}(-1)$ & $-0.254^{* * *}(0.046)$ & $-0.542^{* * *}(0.074)$ \\
\hline
\end{tabular}

The tables show that, both in the short-run as well as long-run regressions, the income coefficients are positive and statistically significant, while the relative price coefficients are negative and statistically significant. Accordingly, any increase in trading partners' incomes will cause the export demand to increase. In contrast, when the relative price between Indonesian and foreign products rises, Indonesian products become relatively more expensive and export demand will decline. Those findings are as expected and consistent with theory.

For both cases, currency volatility significantly influences export in the short run, despite with different directions. The effect is unfavorable for the case of export to Japan, but advantageous in the US case. For the case of Japan, currency fluctuation is also harmful to Indonesian export to Japan in the long-run. The role of commodity price index is negligible in affecting Indonesia's export in the short run in all cases. However, in the long-run, commodity 
price index significantly and positively affects Indonesia's export to Japan, thus implies that any increase in commodity price is advantageous for Indonesia's long-run export to Japan.

The regression outcomes suggest that Japan and the US incomes have significant role in increasing Indonesia's exports, both in the short and long run. Consequently, any rise in the incomes of the two trading partners will stimulate the export demand. On the other hand, the relative price variables have negative and statistically significant coefficients in the short-run as well as in the long-run. Such results imply that any increase in the price of Indonesia's products relative to foreign will reduce the trading partner's imports. Those two findings are as expected and consistent with the international trade theory as pointed out in Section 3. Different findings emerge on the impact of exchange rate volatility and commodity price to both export markets. Specifically, the variables are statistically significant for Indonesia's trade with Japan, but not for Indonesia's trade with the US.

\section{Impact of exchange rate volatility on exports}

The regressions outcomes (Table 6 and Table 7) show that rupiah movement is harmful to Indonesia's trade with the Japanese market. It applies not only in the short run but also in the long-run. Such finding is consistent with an empirical study by Rajan and Siregar (2004) which takes the sample period of 1980Q2 to 1997Q2, or the period before Indonesia began to float its exchange rate. In this context, it is noteworthy to mention that combining the sample period being examined in this study together with the sample period observed by Rajan and Siregar (2004), we can conclude that rupiah fluctuation against Japanese yen dampened Indonesian export to Japan during the last 35 years.

Unlike its impact on Indonesia's trade with Japan, the effect of rupiah fluctuation on Indonesia's long-run export to the US is negligible, while the impact is significantly positive in the short run. Such finding is consistent with the previous study by Bahmani-Oskooee, et al. (2015) on 32 US industries who are importers of Indonesian products. Using annual data of 1973-2011, their empirical investigation reveals that almost 50 percent of the industries are positively affected by real exchange-rate volatility in the short-run, while in the long term, the majority of the industries are not affected. Referring to Davis (2014), exchange rate volatility may have a positive impact on export. One of the reason is exchange rate movement tends to follow some pattern as such importers as well as exporters can anticipate and respond to it effectively. This can be relevant for Indonesia because its central bank (Bank Indonesia) commits to maintaining the stability of rupiah against foreign currency by mitigating its volatility through intervention in the foreign exchange market (www.bi.go.id). In addition, some fundamental macroeconomic issues that Indonesia is dealing with, for example, the current account deficit, inflation, oil subsidy burden, along with relatively shallow financial market, cause the task of maintaining the exchange rate stability to be more challenging, and make it possible for market players to foresee the tendency of rupiah movement. 
The dissimilar responses of export to currency movement between the two markets can also be attributed to several other factors. Firstly, it may relate with the elasticity of import demand of both countries (Fang, 2006). If the demand is inelastic then changes in the exchange rate may not significantly affect the demand. Secondly, differences in risk averseness of producers result in different reaction to exchange rate risks. It is widely accepted that exchange rate volatility generates uncertainty and risk in doing international business (Auboin and Ruta 2012). Responding to such risk, risk-averse producers will shift from the international market to domestic markets, thus export will decline. In contrast, less risk-averse traders tend to export more as exchange rate risks intensify. Their motives may be to avoid any contraction in revenues, or to cover the sunk cost and fixed costs they have already borne, or because they have protected themselves from the exchange rate risk through the use of hedging instruments (UNCTAD, 2013).

\section{Impact of commodity price on export}

The regression results also demonstrate that movement in commodity price index does not affect Indonesia's exports to both countries in the short run. However, its impact on Indonesia's long-run export to Japan is significantly positive. Such different sensitivity between the two foreign markets can be due to the difference in the composition of products shipped to both countries. Shipments from Indonesia to Japan are substantially dominated by natural resources. Specifically, during 1998 to 2015, mineral fuels account for 52 percent of total shipment, while the next 14 percent comprise various types of metals and woods and articles thereof (Figure 10).

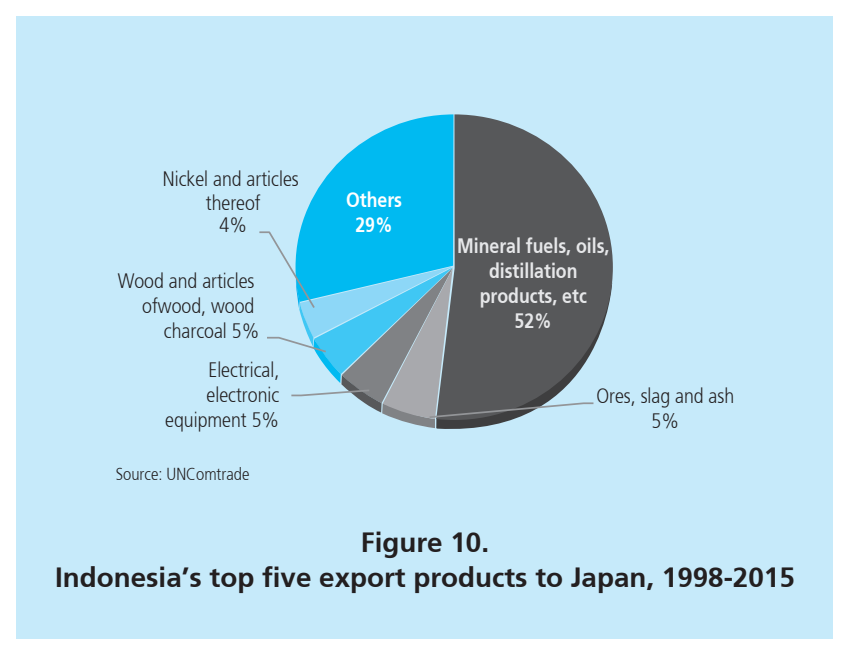


In contrast to Indonesia's export to Japan, the structure of Indonesia shipment to the US constitutes numerous and balanced manufacturing products, such as apparel, rubber goods, electrical equipment, and footwear (Figure 11). Therefore, we can expect that Indonesian export to the US is not sensitive to commodity price.

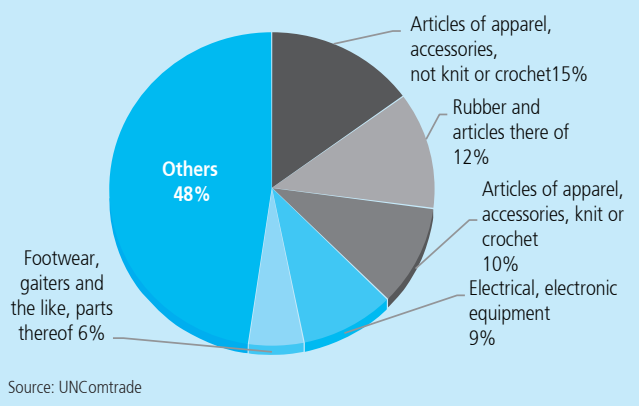

Figure 11.

Indonesia's top five export products to the US, 1998-2015

\subsection{Further investigation on Indonesia's trade with Japan}

The fall in Indonesia's trade to Japan, along with marginally unstable CUSUMSQ of the export demand model (Figure 6), provides an impetus for a deeper investigation. Referring to the figure, instability appears during January 2013 to September 2015. In reality, there are several major economic events during those time interval which may account for the instability. First, the launch of the Japanese economic policy package, also known as "Abenomics", by the Prime Minister Shinzo Abe at the end of December 2012. The policy comprises quantitative easing, fiscal stimulus, and structural reform. Aiming to reactivate the Japanese economy, the policy has caused the yen to weaken against the USD and rupiah to appreciate against the yen (Figure 12).

The second key economic episode took place in May 2013 when the US Federal Reserve signaled its intention to unwind or taper their quantitative easing (QE) policy. The 'tapering talk' surprised the markets and triggered foreign capital reversal which generated sharp depreciation in several emerging market countries, including Indonesia. The third event is enforcement of the 2009 Minerals and Coal Mining Law on raw mineral exports ban on 12 January 2014 by the Indonesian government. The law was preceded by a regulation which set tighter requirements on the exportation of 65 types of raw minerals - excluding coal — and the imposition of a 20 percent export tax on 6 May 2012. 


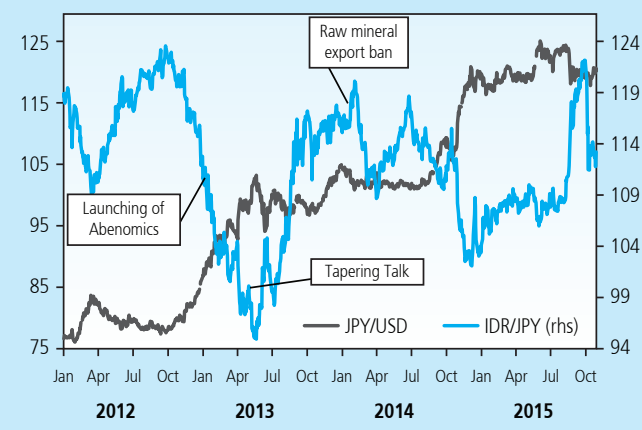

Figure 12.

Daily JPY/USD and IDR/JPY, Jan 2012 - Oct 2015

To confirm whether those events have a sizeable impact on Indonesia's bilateral export to Japan, an empirical examination is undertaken using Eq. (1), added with dummy variables on the launching of Abenomics and the commencement of raw mineral export ban as specified by Eq. (7). The 'tapering talk' is not included because the impact is already captured by the movement of yen. The regression results are reported in Table 9 and Table 10.

$$
\begin{gathered}
\ln X_{1 t}=\alpha_{11}+\alpha_{21} \ln Y_{1 t}+\alpha_{31} \ln R P_{1 t}+\alpha_{41} V_{1 t}+\alpha_{51} D_{1 t}+\alpha_{61} \ln C_{t}+\alpha_{71} D_{-} A b e_{t} \\
+\alpha_{81} D_{-} L a w_{t}+e_{1 t}
\end{gathered}
$$

\begin{tabular}{|c|c|}
\hline \multicolumn{2}{|c|}{$\begin{array}{c}\text { Table } 9 . \\
\text { Estimates of Long-Run Coefficients }\end{array}$} \\
\hline Variable & Long-run coefficients \\
\hline Income & $0.804^{* * *}(0.286)$ \\
\hline Relative Price & $-0.924^{* * *}(0.194)$ \\
\hline RER Volatility Index & 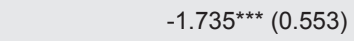 \\
\hline Commodity Price Index & $0.624^{\star * *}(0.149)$ \\
\hline GFC Dummy & $0.253^{\star * *}(0.090)$ \\
\hline Abenomics Dummy & -0.013188 \\
\hline Law Dummy & -0.0171 \\
\hline
\end{tabular}




\begin{tabular}{l|r|}
\multicolumn{2}{c}{ Table 10. } \\
\multicolumn{1}{c}{ Estimates of Short-Run Coefficients } \\
Variable & Short-run coefficients \\
D(Export Volume (-1)) & $-0.196^{\star * *}(0.065)$ \\
D(Income) & $0.249^{\star * *}(0.078)$ \\
D(Relative Price) & $-0.950^{* * *}(0.144)$ \\
D(RER Volatility Index) & $-0.645^{\star *}(0.279)$ \\
D(Commodity Price Index) & $0.074(0.132)$ \\
D(GFC Dummy) & $0.041(0.093)$ \\
D(Abenomics Dummy) & $-0.012(0.092)$ \\
D(Law) & $-0.199^{* *}(0.091)$
\end{tabular}

The results suggest that Abenomics significantly decreased Indonesian export in the long-run, whereas the ban of raw mineral export significantly reduced export, both in the long-run as well as short-run. It implies that the ban can be detrimental for Indonesia's export to Japan. Despite the period being tested (January 2014 to October 2015) is relatively short, the conclusion that the ban is harmful can be justified given the fact that Indonesia's bilateral export has been persistently lagging behind that of its peer countries. Comparisons among the ASEAN5 members show that trade intensity between Japan and some other countries have not dropped as sharp and persistent as trade with Indonesia (Figure 13).

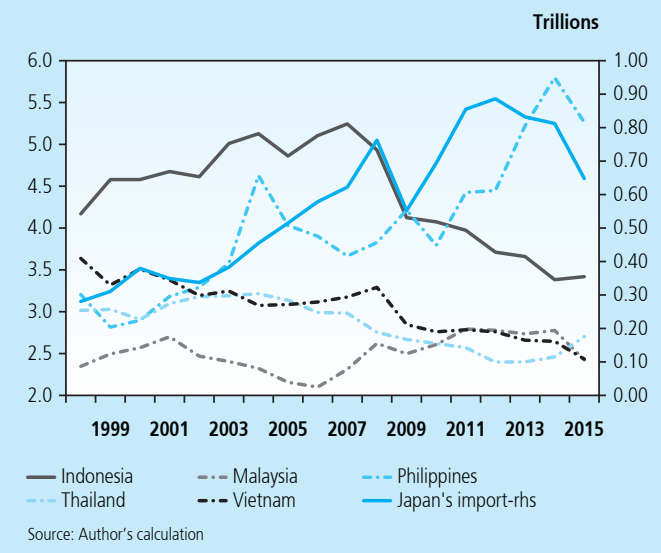

Figure 13. Japan world import (USD trillions) and trade intensity, 1998-2015 


\section{CONCLUSION}

Using the ARDL bounds tests and error-correction-model we can conclude that foreign income has a positive effect on real export volume, whereas relative price negatively affects export. In addition, volatility between Indonesian rupiah against Japanese yen reduces export to Japan, both in the short-run and long-run. The finding also indicates that exchange rate volatility benefits Indonesia's short-run export to the US, but the impact is not carried out into the long-run. The role of commodity price only positively influences the long-run trade with Japan.

For policy-making, the findings suggest that taking into account on the impact of exchange rate volatility on export, monetary authority can take into consideration moderating the fluctuation of Indonesian rupiah against the Japanese yen. The government should also diversify its export products and reduce the commodity-dependency of its exports and optimize the benefits of Indonesia-Japan Economic Partnership Agreement (IJEPA), a bilateral tradeagreement that was signed in 2008. In addition, the authority should improve the availability of hedging instruments and promote the use of hedging among the exporters to support them in coping with exchange rate uncertainty.

Study on the determinants of rupiah volatility against yen will be valuable in order to identify the root causes of the issue and to formulate the appropriate measures. Similar research on the impact of exchange rate volatility on commodity or industry-specific level will also be beneficial, because the impact may differ across sectors. Likewise, further investigation on whether the effect of exchange rate volatility on export is symmetric, that is, whether currency appreciation or depreciation affects Indonesia's trade similarly. 


\section{REFERENCES}

Arize, Augustine C., Osang, Thomas and Slotje, Daniel J. 2008. Exchange-rate Volatility in Latin America and Its Impact on Foreign Trade. International Review of Economics and Finance, 17: 33-44.

Athukorala, Prema-Chandra. 2006. Post-crisis Export Performance: The Indonesian Experience in Regional Perspective. Bulletin of Indonesian Economic Studies, 42(2): 177-211.

Auboin, Marc and Ruta, Michele. 2013. The Relationship between Exchange Rates and International Trade: A Literature Review. World Trade Review, 12(3): 577-605.

Baak, SangJoon. 2008. The Bilateral Real Exchange Rates and Trade between China and The U.S.. China Economic Review, 19: 117-127.

Bahmani-Oskooee, Mohsen and Durmaz, Nazif. 2015. Exchange Rate Volatility and Turkish Commodity Trade with The Rest of The World. Economic Change and Restructuring, 49(1): $1-21$

Bahmani-Oskooee, Mohsen, Harvey, Hanafiah and Hegerty, Scott W. 2015. Exchange Rate Volatility and Commodity Trade between The USA and Indonesia". New Zealand Economic Papers, 49(1): 78-102.

Bustaman, Arief and Jayanthakumaran, Kankesu. 2007. The Impact of Exchange Rate Volatility on Indonesia's Exports to The USA: An Application of ARDL Bounds Testing Procedure. International Journal of Applied Business and Economic Research, 5(1): 1-21.

Chit, Myint M. 2008. Exchange Rate Volatility and Exports: Evidence from The ASEAN-China Free Trade Area. Journal of Chinese Economic and Business Studies, 6(3): 261-277.

Chit, Myint M., Rizov, Marian and Willenbockel, Dirk. 2010. Exchange Rate Uncertainty and Exports: New Empirical Evidence from The Emerging East Asian Economies. The World Economy: 239-264.

Davis, CG. 2014. What Impact Does Exchange Rate Volatility Have on World Turkey Trade Flows? World's Poultry Science Journal, 70: 775-786.

Doğanlar, Murat. 2002. Estimating The Impact of Exchange Rate Volatility on Exports: Evidence from Asian Countries. Applied Economics Letters, 9(13): 859-863.

Fang, WenShwo, Lai, YiHao and Miller, Stephen M. 2006. Export Promotion Through Exchange Rate Changes: Exchange Rate Depreciation or Stabilization? Southern Economic Journal, 72(3): 611-626. 
Edwards, Kim and Sahminan, Sahminan. 2008. Exchange Rate Movements in Indonesia: Determinants, Effects, and Policy Challenges. Bank Indonesia Working Paper, http://www. bi.go.id/en/publikasi/artikel-kertas-kerja/kertas-kerja/Documents/30da02155f76482f94b9 edbfa264b50d2008_WP25_ExchangeratemovementsinIndonesia.pdf/.

Frankel, Jeffrey A., and Rose, Andrew K. 2010. Determinants of Agricultural and Mineral Commodity Prices. Harvard Kennedy School, https://dash.harvard.edu/bitstream/ handle/1/4450126/.

Morgan Stanley. 2013. Preparing for Volatility. Morgan Stanley Research, https://www. morganstanley.com/institutional/research/pdf/FXPulse_20130801.pdf/.

Pesaran, M. Hashem, Shin, Yongcheol and Smith, Richard J. 2001. Bounds Testing Approaches to The Analysis of Level Relationships. Journal of Applied Econometrics, 16(3): 289-326.

Poon, Wai C., Choong, Chee-Keong and Habibullah, Muzafar S. 2005. Exchange Rate Volatility and Exports for Selected East Asian Countries. ASEAN Economic Bulletin, 22(2): 144-159.

Siregar, Reza and Rajan, Ramkishen S. 2004. Impact of Exchange Rate Volatility on Indonesia's Trade Performance in The 1990s. Journal of The Japanese and International Economies, 18(2): 218-240.

Tsen, Wong H. 2014. Exchange Rate Volatility and International Trade. J Stock Forex Trad, 3:2.

United Nations Conference on Trade and Development. 2013. Exchange Rates, International Trade and Trade Policies. Policy Issues in International Trade and Commodities, Study Series no. 56.

UNCTAD, see United Nations Conference on Trade and Development.

Warjiyo, Perry. 2013. Indonesia: Stabilizing The Exchange Rate along Its Fundamental. Bank for International Settlements (BIS) paper no. 73, http://www.bis.org/publ/bppdf/bispap73m.pdf/.

Jeffrey M. Wooldridge. 2013. Introductory Econometrics: A Modern Approach. South-Western Cengage Learning, Mason.

World Trade Organization. 2010. Annual Report, https://www.wto.org/english/res_e/booksp_e/ anrep_e/world_trade_report10_e.pdf/.

WTO, see World Trade Organization.

Marno Verbeek. 2008. A Guide to Modern Econometrics. John Wiley and Sons, Ltd, West Sussex.

Zainal, Arindra A. 2004. Exchange Rate Pass-through, Exchange Rate Volatility, and Their Impacts on Export: Evidence from Indonesian Data. Dissertation, Kansas State University, Manhattan. 
70 Buletin Ekonomi Moneter dan Perbankan, Volume 20, Nomor 1, Juli 2017

Halaman ini sengaja dikosongkan 